\title{
Cognitive decline and depressed level of consciousness in AIDS: Diagnosis
}

\author{
Hein Els, MB ChB, MFamMed, CCFP \\ Department of Diagnostic Radiology, Tygerberg Academic Hospital, Tygerberg
}

\section{Savvas Andronikou, MB BCh, FCRad, FRCR (Lond), PhD}

Department of Diagnostic Radiology and Imaging, University of Limpopo, Medunsa Campus, Garankuwa

Corresponding author: H Els (els.hein@gmail.com)

Please refer to page 30 of the March 2011 issue of the SAJR (http://www. sajr.org.za/index.php/sajr/article/view/450/425) for the presentation details and radiographic images. We congratulate Dr Himal Gajjar (Schnetler, Corbett and Partners, Cape Town) for the precise diagnosis, for which he receives an award of R1 000 from the RSSA. Professor Andronikou and Dr Els elaborate below on the condition and its radiological signs.

\section{Diagnosis and discussion}

The patient was found to have progressive multifocal leucoencephalopathy (PML) - a progressive demyelinating disorder caused by the John Cunningham virus (JCV), which is a DNA papovavirus. It was discovered in 1971 and named after a patient with PML from whom the virus was first isolated. ${ }^{1}$ Epidemiologically, the majority of cases are currently seen in association with AIDS. ${ }^{2}$ The original patient profile was that of chronic disease with immune suppression caused by diseases such as lymphoma, leukaemia, carcinomatosis, sarcoidosis and tuberculosis. ${ }^{3,4}$

Invasion of myelin-producing oligodendrocytes by the JCV causes foci of demyelination. These foci can vary from millimetres to centimetres in size and can occur anywhere, but are frequently found in the cerebral hemispheres and, less commonly, in the cerebellum, brain stem and spinal cord.

PML has an insidious onset of neurological symptoms including impairment of mental state, and disturbance of speech and vision. The disease progresses rapidly and results in end-stage disease characterised by severe disability with dementia, hemiparesis and cortical blindness, ${ }^{5}$ with eventual coma and death.

Histological and virological isolation of the JCV from brain tissue will confirm the diagnosis. Proof of JCV antibodies in serum and/or cerebrospinal fluid (CSF) in isolation does not confirm the diagnosis, but the absence thereof makes the diagnosis of PML highly unlikely.

Computed tomography (CT) findings are described as single or multiple confluent hypodense lesions without mass effect, most commonly in the parieto-occipital white matter. ${ }^{6}$ Fig. 1a demonstrates a right fronto-parietal, right basal ganglia and left anterior capsula externa hypodense lesions without significant mass effect and no contrast enhancement (Fig. 1b).

Magnetic resonance imaging (MRI) is the preferred method of imaging. The lesions are located in the white matter and are widespread and asymmetrical. They are hypo-intense on T1-weighted imaging (WI) and hyperintense on T2WI and FLAIR. Characteristically, there is involvement of the subcortical U-fibres. This feature is best appreciated at MRI and results in the overlying cortex being sharply contrasted with the lesion. ${ }^{7}$

Following CT, our patient underwent an MRI (Fig. 2), which demonstrated $\mathrm{T} 2$ hyperintensity in the right parietal lobe, right basal ganglia and left anterior capsula externa with mild mass effect but no contrast enhancement. Only rarely do such lesions cause mass effect. PML can be differentiated from many other demyelinating diseases by the absence of perivenous inflammation and therefore a lack of enhancement on imaging. Inflammatory PML and HIV-associated PML in the setting of immune recovery following ART may, however, show contrast enhancement. A fluctuant course and interval improvement may occur with PML. ${ }^{8}$

In patients with AIDS, atypical presentations are common, and there may be co-existent central nervous system (CNS) pathologies that will make interpretation of studies more difficult. ${ }^{6}$ Because there is no effective treatment for PML, the prognosis is very poor, resulting in death within 2 - 5 months.

Our patient was diagnosed with PML and commenced on ART. The diagnosis was based on the clinical presentation, imaging findings and polymerase chain reaction (PCR) of cerebrospinal fluid testing positive for JCV. Despite being on ART, the patient presented 2 months later with new neurological symptoms, and a follow-up CT demonstrated significant progression of the lesions (Fig. 3).

\section{Differential diagnoses}

\section{HIVE}

HIV encephalopathy (HIVE) is the most frequent neurological manifestation due to a neurotrophic virus causing direct infection of the CNS. Clinically, patients present with cognitive impairment and motor abnormalities. CT may be normal or show atrophy with or without white matter (WM) lesions. WM lesions are usually bilateral, symmetric, varied in size and manifest as hypodensities. They are seen in the periventricular regions, centrum semiovale, basal ganglia, brainstem and cerebellum. The subcortical WM is spared. MR is the imaging modality of choice, demonstrating lesions of high signal intensity on T2WI and iso-intensity on T1WI. There is no enhancement after contrast administration and no mass effect. ${ }^{9}$

\section{Toxoplasmosis}

The obligate intracellular protozoal parasite Toxoplasma gondii (reservoirs in faeces of the domestic cat) is the most common opportunistic CNS infection in patients with AIDS. ${ }^{7}$ Patients present 
with fatigue, headache, fever and chills. Confusion and drowsiness may follow with seizures, hemiparesis and coma if not treated. Toxoplasma has a predilection for the gray-white matter junction and basal ganglia. CT demonstrates single or multiple hypodense lesions with surrounding oedema and mass effect. On T1WI, the lesions are hypointense and hyperintense on T2WI. On both CT and MRI, lesions may show focal, nodular or rim enhancement. ${ }^{6,8}$ This is an important feature in distinguishing lesions from PML. Occasionally the lesions may haemorrhage, which will aid in differentiating the condition from untreated lymphoma. ${ }^{7}$ Lymphoma usually does not haemorrhage prior to treatment. Often the condition is indistinguishable from PCNSL, and the lack of ependymal spread and additional imaging with single photon emission computed tomography (SPECT) and positron emission tomography (PET) can be helpful. Toxoplasma will be negative at these modalities with lymphoma (typically lager than $2 \mathrm{~cm}$ ) being positive. MR spectroscopy will typically show elevated lactate and lipid.?

\section{Primary central nervous system lymphoma (PCNSL)}

HIV-associated lymphoma may present with symptoms such as headache, lethargy and confusion, often with an insidious onset. Any part of the CNS may be affected, but lesions are found most frequently in the periventricular region, often with subependymal and subarachnoid spread, and can be single or multiple. Multiple lesions favour toxoplasmosis as opposed to lymphoma, while callosal involvement favours lymphoma. The lesions may show oedema and exert mass effect. CT may demonstrate hyperdense or isodense lesions. On MRI, signal is iso- or hypo-intense to gray matter on T2WI and iso- or hypo-intense on T1WI. On both CT and MRI, lesions may show enhancement which may be rim, dense homogenous or nodular in pattern. Untreated lesions typically do not show signs of haemorrhage. At MR spectroscopy, the lesions will show decreased $\mathrm{N}$-acetyl aspartate (NAA) and elevated choline. Elevated lactate and lipid may also appear if the voxel is placed in the necrotic area. ${ }^{7}$

We offer the following simplified flow diagram to use when faced with a similar scenario:

\footnotetext{
1. Padgett, BL, Walker DL, Zu Rhein GM, Eckroade RJ. Cultivation of papova-like virus from human brain with progressive multifocal leucoencephalopathy. Lancet 1971;1:1257-1260.

2. Berger JR, Kaaszovitz B, Post JD, Dickinson G. Progressive multifocal leucoencephalopathy associated with human immunodeficiency virus infection. Ann Intern Med 1984;107:78-87.

3. Richardson EP Jr. Progressive multifocal leucoencephalopathy. N Eng J Med 1961;265;815-823.

4. Astrom KE, Walker DL. Progressive multifocal leucoencephalopathy: a hitherto unrecognized complication of chronic lymphatic leukemia and Hodgkin's disease. Brain 1958;81:93-111.

5. Sweeney BJ, Miller RF, Harrison MJG. Progressive multifocal leucoencephalopathy. Br J Hosp Med 1993;50:187-192.

6. Mark AS, Atlas SW. Progressive multifocal leucoencephalopathy in patients with AIDS: Appearance on MR images. Radiology 1989;173:517-520.
}

\section{Table I. Comparing select features of PML and the differential diagnoses}

\begin{tabular}{|c|c|c|c|c|}
\hline & PML & HIVE & Toxoplasmosis & $\begin{array}{l}\text { PCNSL } \\
\text { (immunocompromised) }\end{array}$ \\
\hline Causative agent & JCV & HIV & Toxoplasma gondii & $\begin{array}{l}\text { Immunodeficiency } \\
\text { predisposes; Epstein-Barr } \\
\text { virus plays a role }\end{array}$ \\
\hline Location & $\begin{array}{l}\text { Frontal, parieto- } \\
\text { occipital; Characteristic } \\
\text { involvement of the } \\
\text { subcortical U-fibres }\end{array}$ & $\begin{array}{l}\text { WM bilateral } \\
\text { periventricular and } \\
\text { centrum semiovale, } \\
\text { basal ganglia, } \\
\text { brainstem, cerebellum. } \\
\text { Subcortical WM spared. }\end{array}$ & $\begin{array}{l}\text { Basal ganglia, thalamus, } \\
\text { cerebral hemispheres } \\
\text { Characteristically the grey- } \\
\text { white interface }\end{array}$ & $\begin{array}{l}\text { Frontal and parietal (most } \\
\text { common), deep gray } \\
\text { nuclei, cluster around } \\
\text { ventricles and extend along } \\
\text { ependymal surfaces, callosal }\end{array}$ \\
\hline Multiplicity & $\begin{array}{l}\text { Often bilateral and } \\
\text { asymmetric }\end{array}$ & Bilateral symmetrical & Often multiple & $\begin{array}{l}\text { Often solitary, may be } \\
\text { multiple }\end{array}$ \\
\hline $\mathrm{CT}$ & Hypodense & $\begin{array}{l} \pm \text { Atrophy } \\
\text { Hypodense }\end{array}$ & Iso- or hypodense & $\begin{array}{l}\text { Hyperdense, may be } \\
\text { isodense }\end{array}$ \\
\hline T1WI & $\begin{array}{l}\text { Iso- and later hypo- } \\
\text { intense }\end{array}$ & Iso-intense & Hypo-intense & Iso- or hypo-intense \\
\hline T2WI & Hyperintense & $\begin{array}{l}\text { Hyperintense: focal or } \\
\text { diffuse }\end{array}$ & $\begin{array}{l}\text { Hyperintense; also iso- or } \\
\text { hypo-intense or target } \\
\text { lesion }\end{array}$ & Iso- or hypo-intense \\
\hline FLAIR & Hyperintense & $\begin{array}{l}\text { Same as T2, but more } \\
\text { conspicuous }\end{array}$ & Hyperintense & $\begin{array}{l}\text { Iso- or hypo-intense, may } \\
\text { be hyperintense }\end{array}$ \\
\hline Enhancement & $\begin{array}{l}\text { Rarely; may enhance, } \\
\text { especially following ART }\end{array}$ & No enhancement & Focal, nodular or rim & $\begin{array}{l}\text { Nodular, rim or } \\
\text { homogenous }\end{array}$ \\
\hline
\end{tabular}




\section{QUIZ CASE}

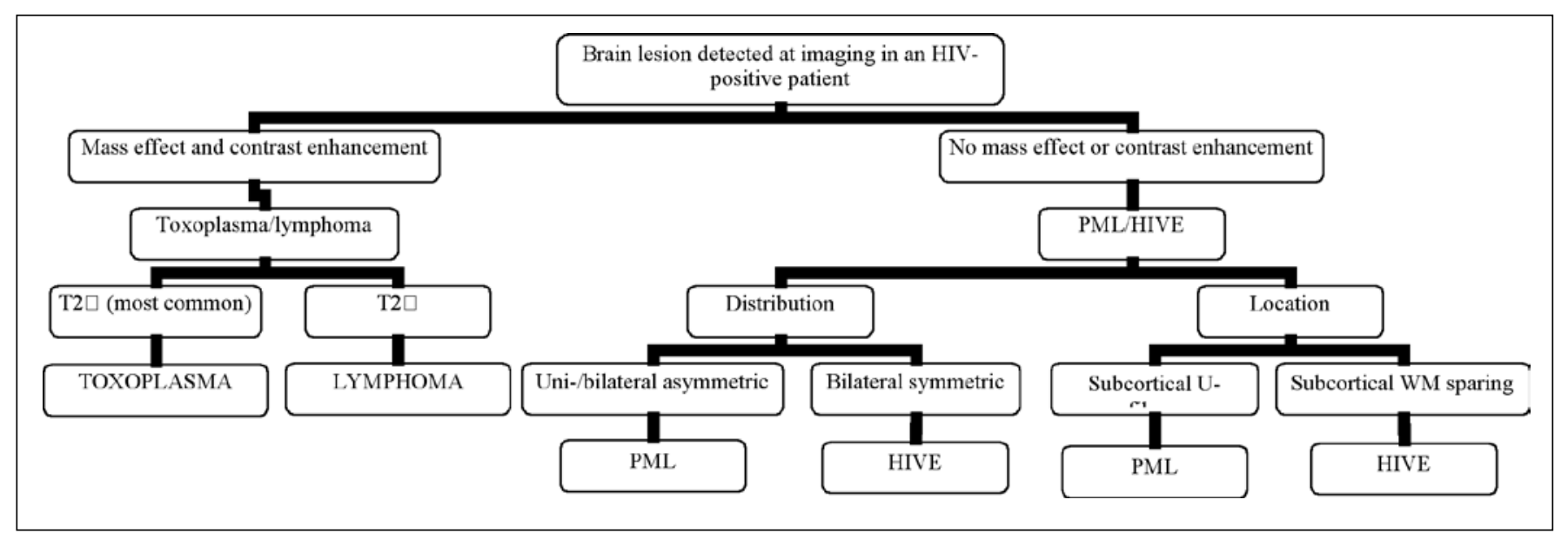

7. Smith AB, Smirniotopoulos JG, Rushing EJ. From the archives of the AFIP: Central nervous system infections associated with human immunodeficiency virus infection: Radiologic-pathologic correlation. RadioGraphics 2008; 28:2033-2058.

9. Osborne AG, Salzman KL, Harnsberger HR, et al. Diagnostic Imaging: Brain. 2nd ed. Utah, USA: Amirsys, 2009.

8. Garrels K, Kucharczyk W, Wortzman G, Shandling M. Progressive multifocal leucoencephalopathy:clinical and MR response to treatment. Am J Neuroradiol 1996;17:597-600. 